\title{
左耳後部に生じた巨大な腫瘤
}

\author{
高橋 秀典 清原 隆宏 熊切 正信 \\ 福井大学医学部感覚運動医学講座皮庙科学
}

要旨 79 歳, 男性。思春期頃から両肩甲骨部に結節があった。2003 年, 左耳後部に小結節が 生じた。徐々に増大し, 手拳大になったため 2006 年 6 月, 当科受診。現症 : 左耳後部の手拳大, 潰瘍を伴う暗赤色腫瘤。両肩甲骨部の羊の角の様な黒褐色結節。家族歴：両親にも同様の腫瘤 があった。病理組織：真皮全層において線維芽細胞が増殖し, 膠原線維は主に表皮と平行に増 生するが，一部ではゆるやかな storiform pattern を呈する。毛細血管は，膠原線維に垂直に 配列して増生する。潰瘍形成部では非特異的な炎症所見が, 背部の腫瘤では膠原線維のヒアリ ン化を伴う。免疫染色：増殖する細胞はビメンチン陽性, $\alpha-\mathrm{SMA}$ 一部陽性, デスミン, CD34, S-100 蛋白は陰性であった。また, Elastica-van-Gieson 染色で弾力線維は証明されない。 診断：ケロイド。治療と経過：無治療で経過観察をしているが, 耳後部と背部の病変に変化は ない。

\section{A giant nodule on the left postauricular area}

Hidenori TAKAHASHI, Takahiro KIYOHARA, Masanobu KUMAKIRI

Department of Dermatology, University of Fukui

An 79-year-old man noticed a small nodule on his left postauricular area about 3 years ago. It gradually became a fist-sized tumor. The surface was red and ulcerated. In addition, there had been brown tumors on both scapular areas since his childhood. Moreover, his parents had similar tumors. Histopathological findings revealed an eosinophilic nodule throughout the dermis. The nodule consisted of fibroblasts, and collagen fibers arranged parallel to the surface epidermis. Partially, a loose storiform pattern was seen. Capillary vessels proliferated perpendicular to the collagen fibers. There was nonspecific inflammation below the ulcer and hyalinization of collagen bundles in places. Immunohistochemical staining showed that the proliferating cells were fibroblasts. Almost all the cells were positive for vimentin, and negative for desmin, CD34, and S-100 protein. $\alpha$-SMA was partially positive. Elastica-van-Gieson staining demonstrated the presence of collagen fibers. We diagnosed this case as keloid. The tumor size has not changed in spite of no particular treatment. [Skin Cancer (Japan) $2007 ; 22: 252-255]$

Key words : Keloid, Giant nodule, DFSP, Elastofibroma 


\section{症例}

\section{患 者：79歳, 男性}

初 診 : 2006 年 6 月

主 訴：左耳後部の暗赤色腫瘤

既往歴：特別なことはない。

家族歴：両親にも同様の腫瘤があった（本人 申告で，詳細は不明）。

現病歴：思春期頃から両肩甲骨部に結節があ り，現在まで大きな変化はない。2003 年に左 耳後部の小さな結節に気付いた。放置していた が，手拳大にまで増大し，表面に潰瘍を形成し たため当科を受診した。

初診時現症：左耳後部に手拳大, 潰瘍を伴う 暗赤色腫瘤がある（図 $1 \mathrm{a}$ )。また，両側肩甲 骨部に羊の角のような外観を呈する長径 $25 \mathrm{~cm}$ ほどの黒褐色結節がある（図1b）。

各種検査所見：血液生化学検査に扔いて, 特 別な異常所見はなく，CTでは，軟部組織や骨 への浸潤はない。

病理組織学的所見：1）HE 染色 耳後部お よび左肩甲骨部ともに，同様の所見を呈する。 真皮全層において好酸性の結節病変が存在して いる（図 2 a)。病変を構成するのは線維芽細

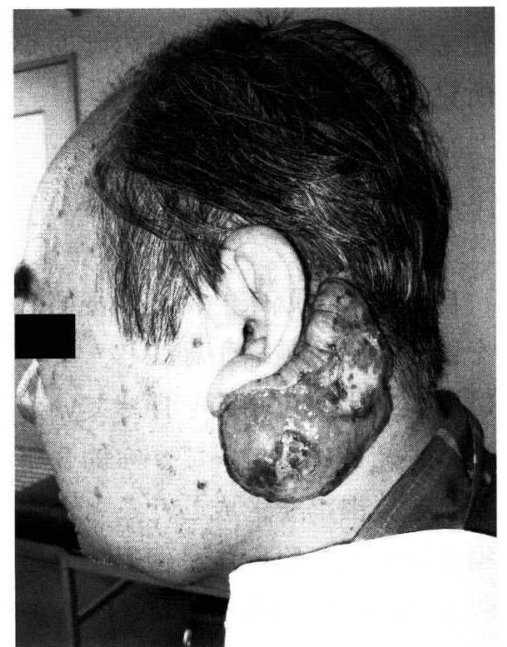

胞様細胞で，膠原線維を伴っており，大部分で は表皮と水平方向に配列しているが（図 2 b)， ゆるやかな storiform pattern を呈する部分も みられる(図 $2 \mathrm{c}) 。$ 。毛細血管は，膠原線維と 直交するように配列して増生している。細胞成 分は粗で，核異型はない。炎症性細胞浸潤は少 ないが，耳後部の潰瘍形成部の真皮浅層では带 状の炎症性細胞浸潤がある。左肩甲骨部では, 細胞成分はかなり粗で，膠原線維が肥厚し，ヒ アリン化がみられる（図 $2 d) 。$

2 ) 特殊染色 増殖する線維芽細胞様細胞 は，ほとんどの細胞でビメンチン陽性（図 3 ）, 耳後部の一部の細胞で $\alpha$-SMA 陽性。デスミン, CD34，S-100 蛋白は陰性であった。Elasticavan-Gieson（以下 EVG と略す）染色において, 弾力線維は存在せず，紅色に染色される膠原線 維が確認された。

治療および経過：無治療にて経過観察をして いるが，耳後部および背部の腫瘤の大きさは変 化なく，耳後部腫瘤の潰瘍は少しずつ縮小して いる。

診 断：自験例は病理組織学的に, 線維芽細 胞および膠原線維が主に表皮と水平方向に増生 し，それらと直交するように毛細血管が配列し ており,これらはケロイドの所見に一致する。

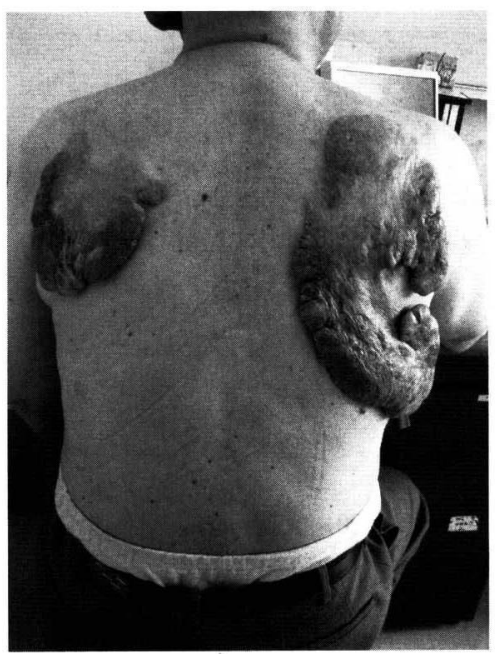

図 1. a. 左耳後部 手拳大で潰瘍を伴う暗赤色腫瘤

b. 两肩甲骨部 羊の角のような外観を呈する黒褐色結節 

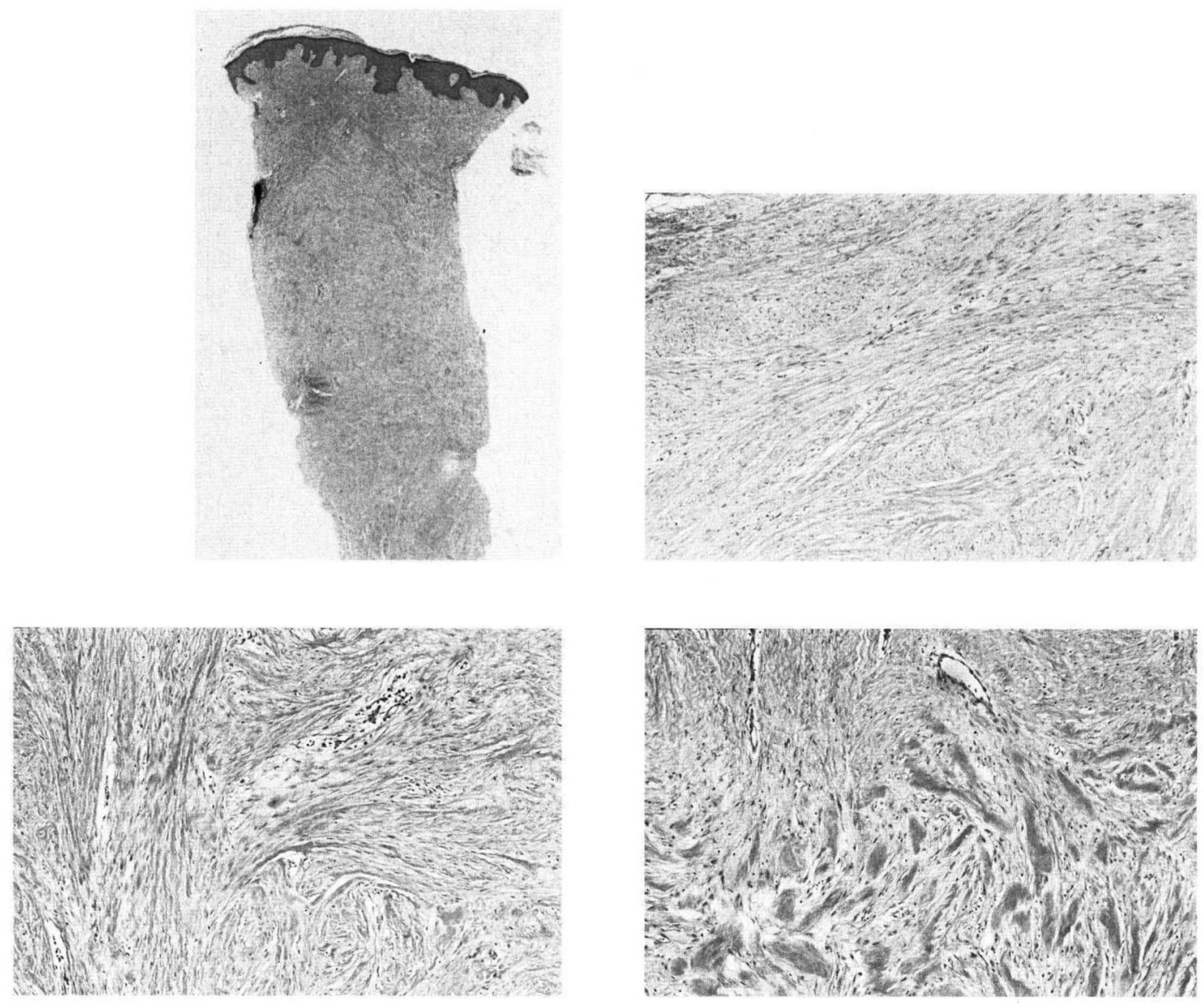

図 2. a. HE 染色 $(\times 40)$ 真皮全層にわたり, 好酸性の結節病変がある
b. HE 染色 $(\times 200)$ 紀鍾形細胞および膠原線維が表皮と平方向に増生している

c. HE 染色 $(\times 200)$ ゆるやかな storiform patternがみられる

d. HE 染色 $(\times 200)$ 膠原線維が膨化してヒアリン化している

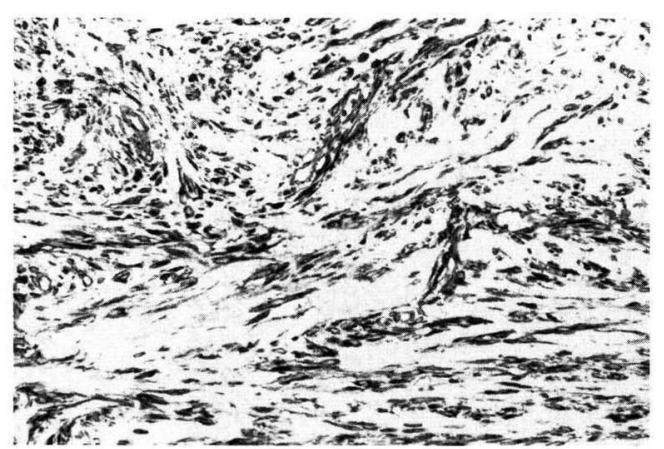

図3、免疫染色

ビメンチン $(\times 200)$ 大部分の細胞において 陽性

また，部分的にゆるやかな storiform pattern を呈することや，膠原線維が膨化してヒアリン
化する所見も，ケロイドの時期や病勢に応じた 所見に合致する。

\section{考按}

自験例は，臨床的に左耳後部に手拳大で潰瘍 を伴う暗赤色腫瘤が存在し，また両肩甲骨部に は巨大な黒褐色結節を伴っている。耳後部の腫 瘤は小結節に気付いてから約 3 年で手拳大まで 増大し，潰瘍を形成したことから，軟部悪性腫 瘍を疑わせる臨床像と経過である。また，肩甲 骨部に巨大な腫瘤を形成する疾患として， elastofibroma が報告されており，鑑別が必要 である。elastofibroma が沖縄の漁師に家族性 
に発症した例1 ${ }^{1}$ も報告されている。

自験例の病理組織像は，線維芽細胞および膠 原線維が主に表皮と水平方向に増生し，それら と直交するように毛細血管が配列するため，ケ ロイドの所見に一致する。部分的にゆるやかな storiform pattern を呈することや，膠原線維が 膨化してヒアリン化する所見も，ケロイドの時 期や病勢に応じた所見に合致する。

軟部悪性腫瘍の中で, DFSP では密に増殖し た紡錘形細胞が，一面に密な storiform pattern を形成し, 免疫染色では CD34 が陽性になるこ とが特徴である。自験例の storiform pattern は一部においてのみ観察され，DFSPのものよ りも，ゆるやかな形状を呈していた。また， CD34 は陰性であった。以上から，DFSP は除 外できる。

fibrosarcomaでは異型性の強い紡錘形細胞 が密に增殖し, herringbone pattern を呈する が, 自験例の線維芽細胞様細胞は，異型性がな

く, herringbone patternはみられなかった。 以上から, fibrosarcoma も除外できる。

Elastofibromaでは，肥厚した膠原線維間に 豊富な弾力線維が存在するが, 自験例では, EVG 染色に抢いて，紅色に染まる膠原線維が みられるのみで, 弾力線維は存在しなかった 以上から, elastofibroma も除外できる。

以上から，自験例をケロイドと確定診断し た。

ケロイドは微小な外傷などがきっかけで生じ る増殖性の瘏痕組織で, 顔面, 前胸部, 上腕,
背部などに好発し，性差はない。臨床的に境界 明瞭で紅色から褐色の扁平ないし半球状の隆起 を呈し，自験例のようにDFSP やその他の線 維性腫瘍などとの鑑別を要する場合もある ${ }^{3)}$ 。 ケロイドの治療 ${ }^{4)}$ は，ステロイドの外用や局注 が一般的に行われており，近年ではシリコン ジェルシートの有効性も報告されている。外科 的治療は，再発の危険性が高く，手術をきっか けに増悪することも多いことから積極的な立場 はとらないことが多い。手術を施行する場合に は放射線照射を併用することが多い。自験例で は，定期的に経過観察をしているが，大きさに 変化はなく，潰瘍は縮小しており，ケロイドの 経過に矛盾しない。急激に増大する腫瘤をみた 場合，悪性腫瘍のみでなくケロイドも念頭に置 く必要があることを認識させられた興味深い症 例であると考えられる。

\section{文献}

1) Nagamine N, Nohara $Y$, Ito $E$ : Elastofibroma in Okinawa : a clinicopathologic study of 170 cases. Cancer, 50 : 1794-1805, 1982

2 ) Linares HA, Kischer CW, Dobrkovsky M, et al: The histiotypic organization of the hypertrophic scars in humans. J Invest Dermatol, 59 : 323-331, 1972

3 ) Kanaar P, Oort J : Fibrosarcomas developing in scar tissue. Dermatologica, 138:312-319, 1969

4) 菊池かな子：ケロイド, 肥厚性癞痕.玉置邦彦, 他編「最新皮唐科学大系」, 第 13 巻, 第 1 版, 中 山書店，東京，2002，45-48 